\title{
Germline MEN1 mutations in sixteen Japanese families with multiple endocrine neoplasia type 1 (MEN1)
}

\author{
Noritaka Hai ${ }^{1,3}$, Norihiko Aoki ${ }^{3}$, Akira Matsuda ${ }^{1,4}$, Toru Mori ${ }^{1,5}$ and Shinji Kosugi ${ }^{1,2}$ \\ Department of ${ }^{1}$ Laboratory Medicine and ${ }^{2}$ Clinical Genetics Unit, Kyoto University School of Medicine, Kyoto 606-8507, Japan, ${ }^{3}$ Second Division, \\ Department of Internal Medicine, Kinki University School of Medicine, Osaka-Sayama, Osaka 589-O014, Japan, ${ }^{4}$ Department of Internal Medicine, \\ Kin-ikyo Chuo Hospital, Sapporo 007-0870, Japan and ${ }^{5}$ Department of Internal Medicine, Takeda Hospital, Kyoto 606-8558, Japan
}

(Correspondence should be addressed to S Kosugi, Department of Laboratory Medicine, Kyoto University School of Medicine, 54 Kawahara-cho, Shogoin, Sakyo-ku, Kyoto 606-8507, Japan; Email: kosugi@kuhp.kyoto-u.ac.jp)

\begin{abstract}
Objective: Multiple endocrine neoplasia type 1 (MEN1) is a syndrome of endocrine tumors involving the parathyroids, anterior pituitary and enteropancreatic neuroendocrine tissues, and is inherited in an autosomal dominant manner. Recently, the gene responsible for this syndrome, MEN1, was positionally cloned in 11q13. We aimed to assess the significance of MEN1 gene diagnostics in families with MEN1.

Design: Sixteen probands of familial MEN1 and their 40 family members were subjected to the study. Methods: Full-length sequencing of the open reading frame and exon-intron boundaries in the MEN1 gene was performed with probands of familial MEN1. Family members were examined for the identified mutation in the proband.

Results: We identified heterozygous germline mutations of the MEN1 gene in all of 16 Japanese MEN1 families examined, achieving the highest detectability of MEN1 mutations in familial MEN1 among studies that examined more than 10 families. Eleven kinds of the identified MEN1 germline mutations were novel. More than half were nonsense or frameshift mutations resulting in a premature stop codon $(9 / 15 ; 60 \%)$, and no mutation hot spots or no apparent genotype-phenotype relationships were observed, in support of the results of other studies. We identified 40 mutant MEN1 gene carriers and 16 non-carriers in the course of the present study in those families.

Conclusions: Analysis of the germline mutations in the MEN1 gene, providing significantly useful clinical information to probands and family members of MEN1, should be considered as a standard procedure and categorized as belonging to Group 1 cancer predisposition testing by the American Society of Clinical Oncology.
\end{abstract}

European Journal of Endocrinology 141 475-480

\section{Introduction}

Multiple endocrine neoplasia type 1 (MEN1; online Mendelian inheritance in man (OMIM) no. 131 100), first reported by Wermer (1) in 1954, is an autosomal dominant disorder characterized by varying combinations of tumors involving the parathyroids (90-100\%), enteropancreatic neuroendocrine tissues (30-75\%) and the anterior pituitary $(50-65 \%)$, with penetrance higher than $90 \%$ by 50 -year-old patients $(2,3)$. With the exception of gastrinomas, most of the tumors are non-metastasizing. In addition to mass effects, striking clinical features develop due to hypersecretion of endocrine substances (4).

The MEN1 locus was mapped by linkage analysis to $11 \mathrm{q} 13$ in 1988 (5), and the gene responsible for the disease, MEN1, was positionally cloned in 1997 (6). The MEN1 gene is $9.2 \mathrm{~kb}$ in length and contains
10 exons. The 610 amino acid translation product named menin is encoded by exons 2-10, and contains neither a signal peptide nor any transmembrane regions. Northern blotting analysis identified a transcript of $2.8-2.9 \mathrm{~kb}$ that was expressed in roughly similar amounts in all adult tissues examined, including leukocytes $(6,7)$. Menin is localized mainly in the nucleus but has no consensus nuclear localization signal (NLS) (8). Guru et al. (8) identified two functionally independent NLS (NLS-1 at residues 479-497 and NLS-2 at residues 588-608) in the Cterminal quarter of menin by site-directed mutagenesis and immunocytochemical analysis. Recently, Agarwal et al. (9) reported that menin interacts with the AP1 transcription factor JunD and represses JunD-activated transcription.

Most of the inherited cancer syndromes (with the notable exception of MEN2 and papillary renal call 
carcinoma) are caused by abnormalities in tumor suppressor genes (10). MEN1 is a putative tumor suppressor gene, and according to Knudson's two-hit model, heterozygous germline mutation of this gene underlies the inherited predisposition to tumorigenesis.

Offspring of an affected individual are at a 50\% risk of inheriting the mutant MEN1 gene and developing various endocrine tumors. Earlier detection of these tumors by screening may help to reduce the morbidity and mortality in this high-risk population. It is important to study the role of MEN1 gene diagnostics in young individuals at risk to assess the value of identifying or excluding the presence of a mutation before the onset of symptoms. Accurate determination of gene carriers at the preclinical stage will help to answer the crucial question of whether earlier diagnosis and treatment can reduce morbidity and mortality.

To date, of 300 MEN1 families analyzed, $>80 \%$ were shown to be positive for MEN1 gene mutation (11-16). MEN1 mutations have been characterized as follows: (a) more than half of the mutations cause truncation of menin, probably resulting in loss-offunction; (b) there are no differences in the nature or distribution of MEN1 mutations between familial and sporadic cases; (c) there are no apparent hot spots for MEN1 mutation; (d) at least $10 \%$ of MEN1 mutations are de novo; and (e) there is no apparent genotypephenotype relationship.

In the present study, we analyzed and identified MEN1 germline mutations in all of 16 MEN1 families examined, supporting the practical importance of MEN1 gene diagnostics in following up family members of patients with MEN1.

\section{Subjects and methods}

\section{Clinical diagnosis}

The diagnosis of MEN1 was based on the presence of tumors in two or more of the three principal systems; i.e. parathyroid, anterior pituitary and enteropancreatic neuroendocrine tissues (6). Diagnosis of familial MEN1 required at least one first-degree relative with a tumor in one or more of these systems. Detailed family histories were obtained from the probands and available family members. Individual tumors were classified according to the clinical features (6).

\section{Genomic DNA extraction, PCR and direct sequencing}

Procedures followed were in accordance with the ethical methods of the institutional committee. Prior to participation in this study, informed consent was obtained from all subjects. Genomic DNA was extracted using a blood kit (Wako, Osaka, Japan) from the patients and their family members (17). Each exon was amplified by PCR with a pair of primers derived from the flanking introns (Table 1). Exons 5 and 6 were co-amplified with the intervening intron. The 3 '-end of intronic primers were 38-96 nucleotides distant from the $5^{\prime}-$ or $3^{\prime}$-end of the exons. The following PCR conditions were applied unless otherwise noted in Table 1 . The PCR reactions were performed in $50 \mu \mathrm{l}$ buffer $(50 \mathrm{mM} \mathrm{KCl}, 1.5 \mathrm{mM}$ $\mathrm{MgCl}_{2}, 10 \mathrm{mM}$ Tris-HCl, pH 8.3) containing $0.2 \mathrm{mM}$ each dNTP, $0.5 \mu \mathrm{M}$ each primer, $100 \mathrm{ng}$ genomic DNA and 1.0 U TaKaRa Taq DNA polymerase (TaKaRa, Tokyo, Japan). Samples were denatured for $5 \mathrm{~min}$ at $94^{\circ} \mathrm{C}$ and then subjected to 35 cycles consisting of $1 \mathrm{~min}$ at $94^{\circ} \mathrm{C}, 1 \mathrm{~min}$ at $58^{\circ} \mathrm{C}$ (exon 2,7 and 10 were $60^{\circ} \mathrm{C}$ ), and $1 \mathrm{~min}$ at $72^{\circ} \mathrm{C}$ using a thermal sequencer (TSR-300; Iwaki, Kyoto, Japan). The last extension was carried out at $72{ }^{\circ} \mathrm{C}$ for $10 \mathrm{~min}$. The PCR products were purified after agarose gel electrophoresis using Ultrafree-MC filter units (Millipore, Bedford, MA, USA). Nucleotide sequences of exonic regions from nucleotide 88 to 1988 covering the full-length coding region, and those of intronic regions at exon-intron boundaries containing at least 38 nucleotides, where critical sequences for splicing are expected to exist (18), were determined in both orientations in all the probands by direct sequencing with a DNA sequencer 373A (Perkin-Elmer, Foster City, CA, USA) and Dye Terminator Cycle Sequencing kits (Perkin-Elmer) according to

Table 1 The primers and conditions for PCR amplification of MEN1 gene coding regions.

\begin{tabular}{|c|c|c|c|c|c|}
\hline Exon & Forward primer ${ }^{a}$ & Reverse primer $^{\mathrm{a}}$ & $\begin{array}{l}\operatorname{Size}^{b} \\
\text { (bp) }\end{array}$ & $\begin{array}{c}\text { Temperature }^{\mathrm{c}} \\
\left({ }^{\circ} \mathrm{C}\right)\end{array}$ & PCR buffer \\
\hline 2 & AAGCAGGGGAGCTGTGCGTGT & CACCTGCCGAACCTCACAAGG $^{d}$ & 685 & 60 & $\mathrm{~N} 5^{\mathrm{e}}$ \\
\hline 3 & TCACTACCTGGCCCCTTTCCC $^{d}$ & TGGAGTCCCTTGGGTGGCTTG ${ }^{\mathrm{d}}$ & 346 & 58 & $S^{f}$ \\
\hline 4 & CCCTGAAGCAGGCACAGGGTG $^{d}$ & CTGCCCAGGGTCCCACAGCAA $^{d}$ & 256 & 58 & $\mathrm{~S}$ \\
\hline $5+6$ & CCACCTCTGCCCGATAGGCTA $^{d}$ & CTCATCTGCCCAGATGAGGGC & 362 & 58 & $\mathrm{~S}$ \\
\hline 7 & CATTTGTGCCAGCAGGGCAGC ${ }^{\mathrm{d}}$ & TGGACGAGGGTGGTTGGAAAC & 274 & 60 & $\mathrm{~S}$ \\
\hline 8 & CTGGGGCTACCCCCGATGGTG ${ }^{d}$ & CCATGGCCCTGTGGAAGGGAG ${ }^{d}$ & 268 & 58 & $\mathrm{~S}$ \\
\hline 9 & CTGGCCTGTGCCCTCTGCTAA ${ }^{d}$ & AAAGTCTGACAAGCCCGTGGC ${ }^{d}$ & 302 & 58 & $\mathrm{~S}$ \\
\hline 10 & TTCGGTGCCGATGGGACTGAG & GGGCTCAGAGTTGGGGGACTA $^{d}$ & 666 & 60 & $\mathrm{~S} 10^{\mathrm{g}}$ \\
\hline
\end{tabular}

${ }^{a}$ From $5^{\prime}$ to $3^{\prime} ;{ }^{b}$ size of PCR product; ${ }^{c}$ annealing temperature; ${ }^{d}$ the primers also used for sequencing; ${ }^{e}$ buffer N5: $15 \mathrm{mM}$ ammonium sulfate, $2.0 \mathrm{mM} \mathrm{MgCl}_{2}, 60 \mathrm{mM}$ Tris- $\mathrm{HCl}, \mathrm{pH} 10.0,5 \%(\mathrm{v} / \mathrm{v}) \mathrm{DMSO} ;{ }^{\mathrm{f}}$ standard buffer as described in Subjects and Methods; ${ }^{\mathrm{g}}$ buffer S10: standard buffer with $10 \%(\mathrm{v} / \mathrm{v})$ DMSO. 
the manufacturer's protocol. Primers used for sequencing are also listed in Table 1 and 5'-GAACCTTAGCG GACCCTGGGA-3' and 5'-TTCCCGAGCTCACCTTCCA GC-3' for forward direction of exon 2, 5'-ATAGACAGG TCGGCCACGGGA-3' for reverse direction of exon 2, 5'GCCCCTGCCTCAGCCACTGTT- $3^{\prime}$ for reverse direction of exons 5 and $6,5^{\prime}$-GGTCCTGGAGTTCCAGCCACT-3' and 5'-AAGCCTCCTGGGACTGTCGCT-3' for forward direction of exon 10 and $5^{\prime}$-ATGCTGCGGGTGCTGGCACCT-3' for reverse direction of exon 10. When PCR products of two different sizes were separated on agarose or $6 \%$ non-denaturing polyacrylamide gels, each DNA band was purified and sequenced separately. When a mutation was identified, family members were examined for the mutation by restriction analysis, polyacrylamide gel electrophoresis or direct sequencing (Table 2). Mutations are named according to standard nomenclature (19).

All mutations were confirmed to be heterozygous and none of the patients was found to have more than one MEN1 gene mutation. All mutations (Table 2) were confirmed by at least two independent experiments.

\section{Results}

We identified heterozygous germline MEN1 mutations in all the probands of 16 unrelated Japanese MEN1 families (Table 2). We identified 24 mutant gene carriers and 16 non-carriers among the family members; the non-carriers had no MEN1-related lesions (Table 2). The occurrence of tumors in the three major systems in all MEN1 mutant carriers examined in this study was $32 / 40(80 \%)$ for the parathyroids, $8 / 40(20 \%)$ for the anterior pituitary and 17/40 (43\%) for enteropancreatic neuroendocrine tissues.

In total, 15 kinds of heterozygous MEN1 germline mutations were identified in 16 families. Eleven kinds were novel for germline MEN1 mutations (Table 2). The 15 kinds of mutations consisted of four missense mutations, five deletions, three insertions, one nonsense mutation and two abnormal splicings. More than half were nonsense or frameshift mutations resulting in a premature stop codon $(9 / 15 ; 60 \%$, the incidence similar to that reported by other groups $(70 / 107 ; 65 \%)(11$, 12)). Further, no mutation hot spots or apparent genotype-phenotype relationships were observed among the 40 carriers of MEN1 mutation.

It is likely that the three missense base substitutions identified in this study (W183R, G225R, C241Y and S253P) were missense mutations and not common benign polymorphisms because they were not detected in 94 independent alleles. Further, the existence of the missense mutations and appearance of MEN1-related lesion(s) in the family members were never contradictory.

Intronic nucleotide alteration was found in two probands. Unfortunately, however, no fresh blood samples for RNA preparation were obtained in the two cases; we failed to demonstrate direct evidences for transcript abnormality. A mutation involving a conserved splice donor site, 1460+1del14insAT, was found in case 11. The first 14 nucleotides of intron 9 were deleted but replaced with an AT dinucleotide. In case 7 , we identified a base substitution, $894-9 \mathrm{G} \rightarrow \mathrm{A}$, creating a new AG at the junction of intron 4 and exon 5. Four mutant carriers among the family members in this study had MEN1 lesions and five members without the mutation had no MEN1-related lesions, suggesting that this substitution was strongly related to the manifestation of MEN1. No $894-9 \mathrm{G} \rightarrow \mathrm{A}$ base substitution was detected in 94 independent alleles.

1650insC was identified in two of our 16 unrelated Japanese MEN1 families and by other groups (11-15). The two families were confirmed to be independent because bases at a polymorphic site (cDNA 1731) on the mutant allele were different (guanine in case 12 and adenine in case 13). Seven consecutive cytosines are present in this region, and such repeat sequences are prone to mutation due to polymerase slippage error (20). 299insCCAGC and 357del4 were identified in unrelated families both in the present study (cases 1 and 2 respectively) and by other investigators $(11-15,21)$. These mutations are present in short repeats and are probably due to replication errors.

1823 delCT identified in case 16 causes a frameshift and is located at the most $3^{\prime}$-site in the MEN1 gene among all the mutations identified to date. This mutation produces a mutant menin protein consisting of 571 normal and 23 alternative amino acids caused by the frameshift. 1823delCT is expected to lack one NLS. No clinical differences were identified in the present study between patients with nonsense or frameshift mutations retaining one NLS (cases 12-16 and their family members) and patients with mutations lacking both NLS.

We identified three major polymorphisms; C2249G (33/108; 31\%), D418D (GAC $\rightarrow$ GAT, 38/93; 41\%) and A541T $(\mathrm{GCA} \rightarrow$ ACA, 24/94; 26\%). Frequencies of C2249G and A541T in Japanese subjects were higher than those in Caucasian populations $(11-13)$ as reported previously $(21,22)$.

\section{Discussion}

Full-length sequencing of the open reading frame of the MEN1 gene is relatively simple because the coding region of the MEN1 cDNA is as short as $2 \mathrm{~kb}$. We achieved the highest detectability $(16 / 16 ; 100 \%)$ of MEN1 mutations in familial MEN1 among studies which examined more than 10 families. MEN1 germline mutations were identified in more than $85 \%$ of MEN1 families investigated when full-length sequencing of the open reading frame was performed $(11,12,15)$, and in about $60 \%$ when some screening technique such as single strand conformational variant analysis was applied $(13,14,16)$. Therefore, analysis of the MEN1 
Table 2 Summary of clinical features of the probands of familial MEN1 in the present study.

\begin{tabular}{|c|c|c|c|c|c|c|c|}
\hline Case & $\mathbf{A g e}^{\mathrm{a}}$ & Sex & $\begin{array}{l}\text { Parathyroid } \\
\text { lesions }\end{array}$ & $\begin{array}{l}\text { Anterior } \\
\text { pituitary } \\
\text { lesion }\end{array}$ & $\begin{array}{l}\text { Enteropancreatic } \\
\text { neuorendocrine } \\
\text { lesions }\end{array}$ & Other lesions & $\begin{array}{c}\text { Germline } \\
\text { MEN1 } \\
\text { mutation }^{\mathrm{b}}\end{array}$ \\
\hline 1 & 54 & $\mathrm{~F}$ & Single & - & Insulinoma & - & 299insCCAGC ${ }^{e}$ \\
\hline 2 & 34 & M & Single & PRL & Multiple carcinoids & - & 357del4 \\
\hline 3 & 30 & M & Multiple & PRL & Multiple NFTs & - & W183R (TGG $\rightarrow$ CGG) \\
\hline 4 & 62 & M & Single & - & Gastrinoma & - & G225R $(G G A \rightarrow A G A)^{f}$ \\
\hline 5 & 38 & $\mathrm{~F}$ & Single & - & NFT & Adrenal NFT & $\mathrm{C} 241 \mathrm{Y}(\mathrm{TGT} \rightarrow \mathrm{TAT})^{\mathrm{f}^{\prime}}$ \\
\hline 6 & 46 & $\mathrm{~F}$ & Multiple & - & Multiple insulinomas & - & S253P $(T C G \rightarrow C C G)^{\dagger}$ \\
\hline 7 & 51 & $\mathrm{~F}$ & Single & - & insulinoma & - & $894-9 G \rightarrow A^{f}$ \\
\hline 8 & 20 & $\mathrm{~F}$ & Single & - & Inappropriate secretion of insulin & - & $1001 \mathrm{del}^{\mathrm{f}}$ \\
\hline 9 & 50 & $\mathrm{~F}$ & Single & - & NFT & - & $1142 \mathrm{delG}^{\dagger}$ \\
\hline 10 & 26 & $\mathrm{~F}$ & Multiple & PRL & - & Lipoma & Q450X (CAG $\rightarrow$ TAG) \\
\hline 11 & 32 & $\mathrm{~F}$ & Multiple & - & NFT & - & $1460+1$ del14insA ${ }^{f}$ \\
\hline 12 & 24 & $\mathrm{~F}$ & Multiple & - & WDHA syndrome & - & 1650insC \\
\hline 13 & 64 & $\mathrm{~F}$ & Single & PRL & Gastrin, calcitonin-secreting tumor & - & 1650insC \\
\hline 14 & 44 & $\mathrm{~F}$ & Single & PRL & Zollinger-Ellison syndrome & - & 1667 ins $^{f}$ \\
\hline 15 & 75 & M & Multiple & - & VIPoma, duodenal carcinoid & - & $1717 \mathrm{del}^{\dagger}$ \\
\hline 16 & 39 & $\mathrm{M}$ & Single & PRL & Hypergastrinemia & Adrenal NFT & $1823 \mathrm{delCT}^{f}$ \\
\hline
\end{tabular}

${ }^{a}$ Age at genetic analysis; ${ }^{b}$ standard nomenclature $(19) ;{ }^{c}$ number of retained wild-type amino acids; ${ }^{d i n c l u d i n g ~ p r o b a n d ; ~}{ }^{e}$ insertion of CCAGC at 299 (after 298 and before 299); ${ }^{\dagger}$ novel mutation.

PRL, prolactinoma; NFT, non-functioning tumor; AS, abnormal splicing; WDHA, watery diarrhea hypokalemia achlorhydria; VIP, vasoactive intestinal polypeptide.

gene in MEN1 is clinically significant, although a small proportion of cases of familial MEN1 might be due to germline mutations in unknown genes. This is in marked contrast to hereditary non-polyposis colorectal cancer which can be caused by a mutation in different genes and genetic analysis of which is categorized as belonging to Group 2 cancer predisposition testing by the American Society of Clinical Oncology $(23,24)$. Genetic analysis is essential because half or a quarter of MEN1 cases will be missed by examination of only symptomatic abnormalities or by biochemical screening respectively (12). Thus, among 201 MEN1 mutant carriers, 100 (50\%) had clinical symptoms, 55 (27\%) had biochemical abnormalities without clinical symptoms and 46 (23\%) were unaffected both clinically and biochemically (12). As it is highly likely that germline MEN1 mutations will be found in a proband of familial MEN1, it is also likely that we shall be able to determine whether a patient's family member is a mutant gene carrier or not. If a family member of MEN1 who had histories of urolithiasis or gastric ulcer is shown to be without MEN1 mutation, it relieves anxiety concerning possible development of MEN1-related lesions. Definite and simple determination of carrier status is an apparent superior point of genetic diagnosis in comparison with biochemical screening which can be meaningful with positive results, but never exclude carrier status. It was proposed that mutant MEN1 gene carriers should be followed up for early diagnosis of MEN1-related lesions by annual biochemical testing and radiological examinations every 3-5 years (3). Medical care is dependent on the results of gene diagnostics; analysis of the MEN1 gene should thus be considered a standard procedure. We propose that analysis of the MEN1 gene should be categorized as belonging to Group 1 cancer predisposition testing by the American Society of Clinical Oncology $(23,24)$.

Thakker et al. (25) suggested three potential hot spots for MEN1 mutations; i.e. codons 83 and 84, 209-211 and 514-516. Mutations involving these regions are caused by mechanisms such as DNA-polymerase slippage errors due to short repeats (12), resulting in deletions and insertions but not missense mutations. It is necessary to clarify whether the missense mutations or in-frame deletions actually affect unknown function(s) of menin (11). It is of note that 45 reported missense mutations and in-frame deletions and four novel missense mutations in the present study were at residues conserved between human and mouse homologues (26).

Exon skipping was expected in case 11 with $1460+1$ del14insAT $(27,28)$, but genomic sequences such as AGGTCTGGG (seven out of nine identical) or ACAGGTG (seven out of seven identical), highly homologous to and at a short distance from the original splice site ACAG/gtgaggg, may be used as cryptic sites (28). It has been reported that there are no AG dinucleotides in the acceptor site from -15 to -5 (28, 29). Therefore, $894-9 \mathrm{G} \rightarrow \mathrm{A}$ creating a new $\mathrm{AG}$ at the junction of intron 4 and exon 5 can be a new spliceacceptor site leaving seven bases at the 3 '-end of intron 4. Mutch et al. (16) directly confirmed this splice abnormality in the transcript. Furthermore, the same mutation was identified constitutionally in a sporadic case with adrenocortical tumor which also showed a somatic stop codon mutation (30). On the basis of these 
Table 2 continued

\begin{tabular}{|c|c|c|c|c|c|c|c|c|}
\hline \multirow[b]{2}{*}{ Location } & \multirow{2}{*}{$\begin{array}{c}\text { Mutant } \\
\text { truncated } \\
\text { protein }^{c}\end{array}$} & \multicolumn{3}{|c|}{ Identified polymorphic site } & \multirow[b]{2}{*}{$\begin{array}{c}\text { Family } \\
\text { examination }^{\mathrm{d}}\end{array}$} & \multirow[b]{2}{*}{$\begin{array}{l}\text { Identified } \\
\text { carrier }\end{array}$} & \multirow[b]{2}{*}{$\begin{array}{l}\text { Identified } \\
\text { non-carrier }\end{array}$} & \multirow[b]{2}{*}{ Reference } \\
\hline & & $\begin{array}{c}\text { Genome } \\
2249\end{array}$ & $\begin{array}{c}\text { cDNA } \\
1364\end{array}$ & $\begin{array}{c}\text { cDNA } \\
1731\end{array}$ & & & & \\
\hline Exon 2 & 69 & $\mathrm{C} / \mathrm{C}$ & $\mathrm{C} / \mathrm{C}$ & $G / A$ & Sequence & 1 & 2 & - \\
\hline Exon 2 & 84 & $\mathrm{C} / \mathrm{C}$ & $\mathrm{C} / \mathrm{T}$ & $\mathrm{G} / \mathrm{A}$ & Electrophoresis & 2 & 0 & - \\
\hline Exon 3 & Missense & $\mathrm{C} / \mathrm{G}$ & $\mathrm{C} / \mathrm{C}$ & $\mathrm{G} / \mathrm{A}$ & Smal & 3 & 0 & 31 \\
\hline Exon 4 & Missense & $\mathrm{C} / \mathrm{G}$ & $\mathrm{C} / \mathrm{T}$ & $\mathrm{G} / \mathrm{A}$ & $A|w|$ & 4 & 1 & - \\
\hline Exon 4 & Missense & $\mathrm{C} / \mathrm{C}$ & $\mathrm{C} / \mathrm{T}$ & $\mathrm{G} / \mathrm{A}$ & - & 1 & 0 & - \\
\hline Exon 4 & Missense & $\mathrm{C} / \mathrm{G}$ & $\mathrm{C} / \mathrm{C}$ & $\mathrm{G} / \mathrm{A}$ & Sequence & 2 & 0 & 32 \\
\hline Intron 4 & AS & $\mathrm{C} / \mathrm{G}$ & $\mathrm{C} / \mathrm{T}$ & $\mathrm{G} / \mathrm{G}$ & Alu I & 5 & 5 & 33 \\
\hline Exon 6 & 297 & $\mathrm{C} / \mathrm{C}$ & $\mathrm{C} / \mathrm{C}$ & $\mathrm{A} / \mathrm{A}$ & - & 1 & 0 & - \\
\hline Exon 7 & 344 & $\mathrm{C} / \mathrm{G}$ & $\mathrm{C} / \mathrm{C}$ & $\mathrm{G} / \mathrm{A}$ & Sequence & 3 & 0 & - \\
\hline Exon 9 & 449 & $\mathrm{C} / \mathrm{C}$ & $\mathrm{T} / \mathrm{T}$ & $\mathrm{G} / \mathrm{G}$ & - & 1 & 0 & - \\
\hline Intron 9 & Possible AS & $\mathrm{C} / \mathrm{C}$ & $\mathrm{C} / \mathrm{T}$ & $\mathrm{G} / \mathrm{A}$ & - & 1 & 0 & 34 \\
\hline Exon 10 & 515 & $\mathrm{G} / \mathrm{G}$ & $\mathrm{C} / \mathrm{C}$ & $\mathrm{G} / \mathrm{G}$ & - & 1 & 0 & 35 \\
\hline Exon 10 & 515 & $\mathrm{C} / \mathrm{C}$ & $\mathrm{C} / \mathrm{T}$ & $\mathrm{G} / \mathrm{A}$ & - & 1 & 0 & - \\
\hline Exon 10 & 519 & $\mathrm{C} / \mathrm{G}$ & $\mathrm{C} / \mathrm{T}$ & $\mathrm{G} / \mathrm{G}$ & - & 1 & 0 & 36 \\
\hline Exon 10 & 535 & $\mathrm{C} / \mathrm{G}$ & $\mathrm{C} / \mathrm{T}$ & $\mathrm{G} / \mathrm{G}$ & Dde I & 10 & 4 & 37 \\
\hline Exon 10 & 571 & $\mathrm{G} / \mathrm{G}$ & $\mathrm{C} / \mathrm{C}$ & $\mathrm{G} / \mathrm{G}$ & Xhol & 3 & 4 & 38,39 \\
\hline
\end{tabular}

three reports, we conclude that $894-9 \mathrm{G} \rightarrow \mathrm{A}$ is an apparently disease-causing mutation, although Bassett et al. (12) reported that this alteration was a benign polymorphism with an incidence of $3 \%$. A possible explanation for their results is that the alteration gives rise to the MEN1 phenotype in most populations but not in a specific population, which would suggest the influence of different modifying backgrounds or different environmental influences. Otherwise, it might have been simply due to a typographical error.

\section{Acknowledgements}

We thank J Fujita, A Shimatsu, H Sugawa, S Ichiyama, Y Endo, Y Kasai, F Otsuki, Y Mine for support, M Imamura, M Kato, Y Yasaku, M Beniko, Y Mashio, S Koizuimi, Y Onaka, T Yokota, T Kitawaki, K Mizunashi, M Wakabayashi, E Itagaki, H Katahira, T Takane, S Suzuki, T Baba, K Saito, Y Matsuura, S Nakaishi, Y Kono, H Tsubaki, H Yakushiji, K Miyazaki, K Iwase, K Okamura, T Hirai, S Sasaki, K Ido, H Doihara, I Nozaki, N Shimizu, N Yamada, T Morita, H Matsumoto, Y Hirata for providing samples and information regarding patients and family members, and A Tamada for excellent technical assistance.

This work was supported in part by grants-in-aid for Scientific Research from the Japanese Ministry of Education, Science and Culture (No. 0644128, No. 06671024, No. 07671129, No. 07557353, No. 08671152, No. 09671051 and No. 09257225), Mochida Foundation for Medical and Pharmaceutical Research, Kowa Foundation for Life Science, Shimizu Foundation for Immunology Research, Kyoto University Foundation, Kurozumi Foundation, Inamori Foundation,
Clinical Pathology Research Foundation of Japan, Fujiwara Memorial Foundation, the Mother and Child Health Foundation, Sagawa Foundation for Cancer Research, Kanehara Foundation and SRF for Biomedical Research (all to S K).

\section{References}

1 Wermer P. Genetic aspects of adenomatosis of endocrine glands. American Journal of Medicine 195416 363-371.

2 Trump D, Farren B, Wooding C, Pang JT, Besser GM, Buchanan KD et al. Clinical studies of multiple endocrine neoplasia type 1 . Quarterly Journal of Medicine 199689 653-669.

3 Skogseid B, Rastad J \& Oberg K. Multiple endocrine neoplasia type 1. Clinical features and screening. Endocrinology and Metabolism Clinics of North America 199423 1-18.

4 Kopp P. A long-sought needle in the haystack: the multiple endocrine neoplasia type 1 gene. European Journal of Endocrinology $1997137222-223$

5 Larsson C, Skogseid B, Oberg K, Nakamura Y \& Nordenskjold M. Multiple endocrine neoplasia type 1 gene maps to chromosome 11 and is lost in insulinoma. Nature 1988332 85-87.

6 Chandrasekharappa SC, Guru SC, Manickam P, Olufemi SE, Collins FS, Emmert-Buck MR et al. Positional cloning of the gene for multiple endocrine neoplasia-type 1. Science $1997276404-$ 407 .

7 The European Consortium on MEN1. Identification of the multiple endocrine neoplasia type 1 (MEN1) gene. Human Molecular Genetics 19976 1177-1183.

8 Guru SC, Goldsmith PK, Burns AL, Marx SJ, Spiegel AM, Collins FS et al. Menin, the product of the MEN1 gene, is a nuclear protein. Proceedings of the National Academy of Sciences of the USA 199895 1630-1634.

9 Agarwal SK, Guru SC, Heppner C, Erdos MR, Collins RM, Park $\mathrm{SY}$ et al. Menin interacts with the AP1 transcription factor JunD and represses JunD-activated transcription. Cell 199996 143-152.

10 Pearce SH. Multiple endocrine neoplasia type 1 (MEN1): recent advances. Clinical Endocrinology 199747 513-514.

11 Agarwal SK, Kester MB, Debelenko LV, Heppner C, Emmert-Buck MR, Skarulis MC et al. Germline mutations of the MEN1 gene in 
familial multiple endocrine neoplasia type 1 and related states Human Molecular Genetics 19976 1169-1175.

12 Bassett JH, Forbes SA, Pannett AA, Lloyd SE, Christie PT, Wooding $\mathrm{C}$ et al. Characterization of mutations in patients with multiple endocrine neoplasia type 1. American Journal of Human Genetics $199862232-244$.

13 Giraud S, Zhang CX, Serova-Sinilnikova O, Wautot V, Salandre J, Buisson $\mathrm{N}$ et al. Germ-line mutation analysis in patients with multiple endocrine neoplasia type 1 and related disorders. American Journal of Human Genetics 199863 455-467.

14 Teh BT, Kytola S, Farnebo F, Bergman L, Wong FK, Weber G et al. Mutation analysis of the MEN1 gene in multiple endocrine neoplasia type 1, familial acromegaly and familial isolated hyperparathyroidism. Journal of Clinical Endocrinology and Metabolism $1998832621-2626$.

15 Poncin J, Abs R, Velkeniers B, Bonduelle M, Abramowicz M, Legros JJ et al. Mutation analysis of the MEN1 gene in Belgian patients with multiple endocrine neoplasia type 1 and related diseases. Human Mutation 199913 54-60.

16 Mutch MG, Dilley WG, Sanjurjo F, DeBenedetti MK, Doherty GM, Wells SA Jr et al. Germline mutations in the multiple endocrine neoplasia type 1 gene: evidence for frequent splicing defects. Human Mutation 199913 175-185.

17 Matsuda A \& Kosugi S. A homozygous missense mutation of the sodium/iodide symporter gene causing iodide transport defect. Journal of Clinical Endocrinology and Metabolism 1997823966 3971.

18 Lewin B. Mechanisms of RNA splicing. In Genes IV, pp 578-609. Ed B Lewin. Oxford: Oxford University Press, 1990.

19 Beaudet AL \& Tsui LC. A suggested nomenclature for designating mutations. Human Mutation 19932 245-248.

20 Rodenhiser D, Chakraborty P, Andrews J, Ainsworth P, Mancini D, Lopes E et al. Heterogenous point mutations in the BRCA1 breast cancer susceptibility gene occur in high frequency at the site of homonucleotide tracts, short repeats and methylatable $\mathrm{CpG} /$ CpNpG motifs. Oncogene 199612 2623-2629.

21 Tanaka C, Yoshimoto K, Yamada S, Nishioka H, Ii S, Moritani M et al. Absence of germ-line mutations of the multiple endocrine neoplasia type 1 (MEN1) gene in familial pituitary adenoma in contrast to MEN1 in Japanese. Journal of Clinical Endocrinology and Metabolism 199883 960-965.

22 Sato M, Matsubara S, Miyauchi A, Ohye H, Imachi H, Murao K et al. Identification of five novel germline mutations of the MEN1 gene in Japanese multiple endocrine neoplasia type 1 (MEN1) families. Journal of Medical Genetics 199835 915-919.

23 Statement of the American Society of Clinical Oncology. Genetic testing for cancer susceptibility. Adopted on 20 February 1996. Journal of Clinical Oncology 199614 1730-1740.

24 Garber JE, Offit K, Olopade OI, Fink D, Barbasch A, Barr P et al. The American society of clinical oncology position on genetic testing. Cancer Supplement $199780632-634$.

25 Thakker RV. Multiple endocrine neoplasia - syndromes of the twentieth century. Journal of Clinical Endocrinology and Metabolism $1998832617-2620$.
26 Stewart C, Parente F, Piehl F, Farnebo F, Quincey D, Silins G et al. Characterization of the mouse Men 1 gene and its expression during development. Oncogene 199817 2485-2493.

27 Mount SM. A catalogue of splice junction sequences. Nucleic Acids Research $198210459-472$.

28 Antonarakis SE. Mutations in human diseases: nature and consequences. In Emery and Rimoin's Principles and Practice of Medical Genetics. edn 3, pp 53-66. Eds AEH Emery, DL Rimoin, JM Connor \& RE Pyeritz. New York: Churchill Livingstone, 1996.

29 Seif I, Khoury G \& Dhar R. BKV splice sequences based on analysis of preferred donor and acceptor sites. Nucleic Acids Research 1979 $63387-3398$.

30 Gortz B, Roth J, Speel EJ, Krahenmann A, De Krijger RR, MatiasGuiu X et al. MEN1 gene mutation analysis of sporadic adrenocortical lesions. International Journal of Cancer 199980 373-379.

31 Mashio Y, Beniko M, Ikota A, Mizumoto H, Sato S, Yamaguchi O et al. Long-term bromocriptine treatment for giant prolactinoma: Report of a case. Journal of Japanese Society of Internal Medicine 198978 1785-1786.

32 Wakabayashi M, Sode Y, Kawamura N, Miyazaki T, Ohtsuka M, Sawada $\mathrm{H}$ et al. A family with two cases of multiple endocrine neoplasia type 1. Endocrine Surgery 19885 341-347.

33 Katahira H, Takizawa M, Itagaki E, Miyasaka Y, Kimura M, Maruyama $\mathrm{M}$ et al. Two families of multiple endocrine neoplasia type 1 and genetic analysis of their tumors. Folia Endocrinologica Japonica 199369343.

34 Tsubaki H, Miyashita Y, Himura I, Tokuda N, Harada M, Kase T et al. Surgical treatment of primary hyperparathyroidism in two members of a family with multiple endocrine neoplasia type 1 . Endocrine Surgery 199613 303-308.

35 Yakushiji H, Miyazaki K, Sasatomi E, Nakashiro H, Hisatsugu T, Toda $\mathrm{S}$ et al. Malignant pancreatic endocrine tumor presenting watery diarrhea, hypokalemia, achlorhydria syndrome with multiple endocrine neoplasia type 1 - report of a case. The Biliary Tract and Pancreas 199516 865-870.

36 Mizokami T, Okamura K, Shiroozu A, Matsui T, Nomiyama N \& Fujishima M. Two cases of multiple endocrine neoplasia type 1 . Japanese Journal of Clinical and Experimental Medicine 199370 3895-3899.

37 Matsumoto H, Nomura S, Tanaka S, Nagahiro I, Hirai R, Itano H et al. A case of WDHA syndrome associated with multiple endocrine neoplasia. Gastroenterological Surgery 199528 1943-1947.

38 Miyanishi K, Hirata Y, Ohi S, Ishii T, Ishizaka M, Kiyota M et al. A case of multiple endocrine neoplasia (MEN) type 1. Journal of Medical Association of Southern Hokkaido 199530 216-218.

39 Teramoto J, Hirata Y, Miyanishi K, Katahira T, Ohi S, Ishii T et al. A case of Wermer syndrome improved by administration of somatostatin analogue. Journal of Medical Association of Southern Hokkaido $1996312-4$.

Received 26 April 1999

Accepted 9 July 1999 